\title{
Effect of Organic Amendments, Biofertilizer Consortia and Microbial Antagonists on the Survival of Sheath Rot Pathogen (Sarocladium oryzae (sawada) Gams and Hawksw.
}

\author{
Budha Bora $^{1}$ and Mohammad Sakendar.Ali ${ }^{2}$ \\ ${ }^{1}$ Department of Plant Pathology, Biswanath College of Agriculture, Biswanath Chariali, \\ Assam, Pin-784176, India \\ ${ }^{2}$ Department of Plant Pathology, Assam Agricultural University, Jorhat, \\ Assam, Pin-785013, India
}

\begin{abstract}
Sheath rot has emerged as one of the major diseases of rice inflicting severe yield losses all over the world. The pathogen is seed borne and survives in soil on the leftover stubbles, which acts as the sources of primary inoculums. The present study was therefore undertaken to evaluate the effect of organic amendments, microbial antagonists, and biofertilizer consortia on the survival of sheath rot pathogen. The Sarocladium oryzae could be isolated from infected stubbles and seeds upto 150 and 210 days of storage, respectively irrespective of amended or unamended soil. The fungus could survive only upto 120 days in dhaincha amended plot whereas, it could survive upto 180 days in the control plot at all the soil depths.
\end{abstract}

Keywords: Organic amendment, biofertilizer consortia, Sarocladium oryzae

\section{Introduction}

Rice (Oryza sativa L.) an important staple food of nearly half of the world's population is being affected by a number of fungal, bacterial and bacterial diseases inflicting enormous yield loss. Among the various diseases of rice, sheath rot caused by Sarocladium oryzae (Sawada) Gams and Hawksw has gained the status of a major disease of rice, particularly after the introduction of high yielding varieties and reduces the yield considerably all over the rice growing areas of the world. The disease affects the quality of the rice grains and severe infection reduced the yield as high as 85 percent (Prabhakaran et. al., 1973). The disease causes empty grain production (Kulwant and Mathur,1992) and glume discolouration (Sachan and Agarwal,1995) and also seed discolouration (Reddy et.al., 2000).

The pathogen is seed borne and survives in soil on the leftover stubbles, which acts as the sources of primary inoculums (Reddy et al., 1974). The survival of the pathogen is reported to vary from place to place depending upon the prevalent environment conditions (Singh and Raju, 1980 ; Mohan and Subramanian, 1981).

Organic amendments can reduce soilborne pathogens through enhanced suppressive activity in soil (Mazzola 2004), or mediated by the release of toxic nitrification products from high nitrogen amendments (Tenuta and Lazarovits 2002b). High nitrogen-containing organic amendments have shown effective control of soilborne pathogens (Gamliel et al., 2000). Biofertilizers like Azotobacter and Azospirillum fixes atmospheric nitrogen and secrets plant growth promoting hormones like IAA, GA, thiamine, riboflavin etc, are very useful for making availability of nutrients necessary for sustaining soil fertility and plant health. The use of microorganisms as biological control agents to control plant disease has emerged as powerful alternative method (Kulkarni et al., 2007). Plant Growth Promoting Rhizobacteria, Pseudomonas 
fluorescens also plays an important role as biocontrol agent in management of several soil borne pathogens (Sakthivel and Gnanamanickam, 1987).

Organic amendments and microbial antagonists are known to improve the soil fertility, plant health and can reduce soil-borne pathogens through enhanced suppressive activity in soil or mediated by the release of toxic nitrification products which ultimately influence the survival of the pathogens.

Therefore, the present study was undertaken to assess the effect of organic amendments, biofertilizer consortia and microbial antagonists on the survival of sheath rot pathogen (Sarocladium oryzae (Sawada) Gams and Hawksworth).

\section{Materials and Methods}

\subsection{Field Experiment}

Field trial was conducted during the kharif season of 2017-18 and 2018-19 at the experiment farm, RARS, North Lakhimpur with four replications to test the effect of organic amendments, biofertilizer consortia and microbial antagonist $(P f)$ on the survival of sheath rot pathogen. The experiment was conducted in Randomized Block Design (RBD) with plot size of $5 \times 2 \mathrm{~m}^{2}$. The following treatments were undertaken for the field experiment.

T1: Dhaincha@40 kg seed/ha +BCEF@ $2.5 \mathrm{MT} / \mathrm{ha}+\operatorname{Pf}$ bioformulation

T2: Vermicompost@1 MT/ha +BCEF@ 2.5 MT/ha + Pf bioformulation

T3: Azolla@ 1 MT/ha + BCEF @ 2.5 $\mathrm{MT} / \mathrm{ha}+\operatorname{Pf}$ bioformulation

T4: BCEF @ $2.5 \mathrm{MT} / \mathrm{ha}+P f$ bioformulation

T5: BCEF@2.5 MT/ha

T6: RDF (20:10:10)

T7: Absolute control

\subsubsection{In situ incorporation of Dhaincha as green manure}

Dhaincha ( Sesbania aculeata) as green manure crop was sown @ $40 \mathrm{~kg}$ seed per ha and incorporated into the after 45 days of sowing and kept for decomposition for 20 days before transplanting which served as one of the treatment.

\subsubsection{Application of Azolla:}

Fresh Azolla(Azolla pinnata) was applied @ 1 t/ha 7-10 days after transplanting and incorporated into soil after attaining full growth in 3 weeks which served as one of the treatment.

\subsubsection{Application of Biofertilizer Consortia Enriched FYM (BCEF)}

Biofertilizer Consortia comprising six different microbes viz. PSB, Azospirillum, Azotobacter, Rhizobium, Zinc solubilising bacteria and Potassium solubilising bacteria, were collected from the department of soil science, AAU, Jorhat. These biofertilizer consortia are used to prepare Biofertilizer Consortia Enriched Farm Yard Manures by through mixing with Rock phosphate and FYM @ $10 \mathrm{~kg}$ biofertilizer consortia, $170 \mathrm{~kg}$ Rock phosphate and $820 \mathrm{~kg}$ of FYM, respectively to get one MT of Biofertilizer Consortia Enriched FYM (BCEF). This BCEF was incubated for 7 days and applied in the field at the time of final land preparation@ 2.5 MT per ha.

\subsubsection{Method of application of $P f$ bioformulation}

The talc based $P f$ bioformulation was applied as Seed Treatment (ST) @ 10gm per kg of seed for one litre of water, Seedling Root Dip Treatment (SRDT) @ 10 gm per litre of water for 1hour and Foliar Spray (FS) @ 0.2\% at boot leaf stage.

\subsection{Survival of sheath rot pathogen (Sarocladium oryzae)}

Survival and viability of sheath rot pathogen (Sarocladium oryzae) in the infected rice boot leaf sheath and seeds at laboratory condition and also in the soil at field conditions were studied.

\subsubsection{Survival and viability in infected stubbles}

Infected stubbles in the form of boot leaf sheaths of rice variety Mahsuri were collected from all the experiment plots after harvest of the crop. The boot leaf sheaths were air dried, cut into small pieces and stored in cloth bags separately at room temperature for different periods viz., 30, 60, 90,120,150, 180 and 210 days. After each storage period, 20 boot leaf sheath bits, taken out from each cloth bag, were surface sterilized with 1.0 per 
cent sodium hypochlorite and tested for the presence of $S$. oryzae. The surface sterilized boot leaf sheath bits were equally spaced out aseptically on sterile PDA medium contained in Petri dish at the rate of 20 leaf bits per dish. This constituted one replication and four replications were maintained separately for each storage period. The Petri dishes were incubated at $28 \pm 1^{\circ} \mathrm{C}$. The leaf bits were examined daily under stereoscopic binocular microscope and observations on the number of sheath bits colonized by $S$. oryzae were made and per cent colonization of sheath bits in different storage period was calculated. The experiment was conducted in CRD.

\subsubsection{Survival and viability in rice seed}

Seeds from the infected rice plants of variety Mahsuri were collected from all the experimental plots after harvest of the crop. The seeds were air dried and stored in cloth bags separately at room temperature for different periods viz., 30, 60, 90,120,150, 180 and 210 days. After each storage period, the presence of $S$. oryzae in the seeds was tested employing agar plate method. For each storage period, 20 numbers of seeds were taken out from each cloth bag and surface sterilized with 1.0 per cent sodium hypochlorite and tested for the presence of $S$. oryzae.

The surface sterilized seeds were equally spaced out aseptically on sterile PDA medium contained in Petri dish at the rate of 20 seeds per dish. This constituted one replication and four replications were maintained separately for each storage period. The Petri dishes were incubated at $28 \pm 1^{\circ} \mathrm{C}$. The seeds were examined daily under stereoscopic binocular microscope and observations on the number of seeds colonized by $S$. oryzae were made and per cent colonization of seeds for different storage periods was calculated. The experiment was conducted in CRD.

\subsubsection{Survival and viability of $S$. oryzae in soil from infected rice fields}

Soil samples were collected at various depth viz $0 \mathrm{~cm}, 2 \mathrm{~cm}$ and $4 \mathrm{~cm}$ from all the experimental plots after harvest of the crop at monthly interval. The soil samples so collected at monthly interval were air dried and the presence of $S$. oryzae was tested using Soil Dilution Plate Method (Waksman, 1922) and expressed as cfu/g of soil. Four replications were maintained for each period. The experiment was conducted in CRD.

\subsection{Statistical Analysis}

The experimental data collected were analyzed statistically for its significance of difference by the normal statistical procedure adopted for completely randomized design and randomized block design and interpretation of data was carried out in accordance with Gomez and Gomez (1984). The treatment means were compared by Duncan's Multiple Range Test (DMRT). The package used for analysis was IRRIStat version 92- a developed by International Rice Research Institute, Biometrics Units, The Philippines.

\section{Results and Discussion}

\subsection{Survival and viability of $S$. oryzae in infected stubbles at room temperature}

The data presented in Table 3.1 revealed that the survival and viability of the fungus showed a significant reduction with increase in storage period, even though the fungus could be isolated from the boot leaf sheaths upto 150 days of storage. The survival and viability of $S$. oryzae in boot leaf sheaths stored for 30 days was found to be the highest ( 58.33 per cent) colonization which showed a linear decline to 46.66 per cent, 31.66 per cent and 11.66 percent, after 60, 90 and 120 days of storage respectively. The lowest (3.33 per cent) colonization of fungus was recorded in boot leaf sheaths stored for 150 days at room temperature.

Table 3.1 Effect of storage period on survival and viability of S. oryzae in the infected boot leaf sheaths in vitro

\begin{tabular}{|c|c|c|}
\hline SI No & Storage period (Days) & Percent leaf sheath bits colonized by S. oryzae \\
\hline 1 & 30 & $58.34(49.78)^{\mathrm{a}}$ \\
\hline 2 & 60 & $46.65(43.06)^{\mathrm{b}}$ \\
\hline 3 & 90 & $31.68(34.22)^{\mathrm{c}}$ \\
\hline 4 & 120 & $11.65(19.87)^{\mathrm{d}}$ \\
\hline 5 & 150 & $3.32(8.61)^{\mathrm{e}}$ \\
\hline & $\mathrm{SEd} \pm$ & 1.93 \\
\hline & $\mathrm{CD}(\mathrm{P}=0.05)$ & 3.98 \\
\hline
\end{tabular}

Data are mean of four replications. Data within parenthesis are angular transformed values 
In conformity with the research findings of the present study, Reddy et al. (2001) observed that $S$. oryzae could survive upto three and a half months in the infected boot leaf sheaths under laboratory conditions. However, Maiti et al. (1991) reported that the fungus could survive up to ten months in infected boot leaf sheaths in storage under lab conditions but the fungus could not survive in the infected stubble for more than two months after the harvest in field conditions. Rajendran (1979) and Singh and Raju (1980) observed that the fungus could survive up to ten months in the infected stubble in field conditions. Varati (2012) also observed that the survival and viability of S.oryzae showed a significant reduction with increase in storage period, even though the fungus could be isolated from the boot leaf sheaths even after 120 days.Kawamura (1940) also reported that the mycelium of the fungus $S$. oryzae could survive in diseased tissues for more than 6 months. Shahjahan et al. (1977) observed that the fungus was readily isolated from diseased sheaths and grains kept in the laboratory for more than one year. They reported that the pathogen could survive both in the infected leaf sheaths and seeds upto 10 months. The pathogen was found to survive better in seeds than in sheaths and the optimum temperature for the survival of the pathogen was observed to be $25 \pm 1^{\circ} \mathrm{C}$.

The survival and viability of $S$. oryzae in the infected stubbles (boot leaf sheaths) may be influenced by the environmental conditions prevailing in storage and strain of the pathogen. Similar finding were observed by Maiti et al. (1991) who observed that the differences in the survival period might be due to the environmental conditions and variations in the strains of pathogen. Moisture content was described as one of the important factors for the survival and viability of fungi (Christenen and Kaufmann, 1965). The depletion of moisture level and nutrients in boot leaf sheaths stored for relatively longer periods might be one of the reasons for the decreased presence of $S$. oryzae in the sheaths stored for 150 days relative to the leaf sheaths stored for 30 days in the present study.

Table 3.2 Effect of storage period on survival and viability of S. oryzae in the infected rice seeds in vitro

\begin{tabular}{|c|c|c|}
\hline \multirow{2}{*}{ SI No } & Storage period & \multirow{2}{*}{ Percent seed colonized by S. oryzae } \\
\cline { 2 - 3 } & (Days) & $63.34(52.72)^{\mathrm{a}}$ \\
\hline 1 & 30 & $53.36(46.89)^{\mathrm{b}}$ \\
\hline 2 & 60 & $41.65(40.18)^{\mathrm{c}}$ \\
\hline 3 & 90 & $29.16(32.66)^{\mathrm{d}}$ \\
\hline 4 & 120 & $15.83(23.41)^{\mathrm{e}}$ \\
\hline 5 & 150 & $8.32(16.58)^{\mathrm{f}}$ \\
\hline 6 & 180 & $3.31(6.46)^{\mathrm{g}}$ \\
\hline 7 & 210 & 1.85 \\
\hline & $\mathrm{SEd} \pm$ & 3.76 \\
\hline
\end{tabular}

Data are mean of four replications. Data within parenthesis are angular transformed values 


\subsection{Survival and viability of $S$. oryzae in rice seed}

The survival and viability of the fungus significantly showed reduction with the increase in storage period, even though the fungus could be isolated from the infected seeds even upto 210 days (Table 3.2). The survival and viability of $S$. oryzae in seeds stored for 30 days was found to be the highest (63.33 per cent) colonization which showed a linear decline to $53.33,41.66,29.16,15.83$ and 8.33 per cent after $60,90,120,150$ and 180 days of storage, respectively. The lowest (3.33 per cent) colonization of fungus was recorded in seeds stored for 210 days at room temperature.

The result of the present study was in accordance with the findings of Gopalakrishnan and Valluvaparidasan (2006) who observed that the $S$. oryzae survived in rice seeds stored for 90 days and there after it declined in all the seed samples. Shahjahan et al. (1977) observed that the fungus was readily isolated from diseased sheaths and grains kept in the laboratory for more than one year. They reported that the pathogen could survive both in the infected leaf sheaths and seeds upto 10 months. The pathogen was found to survive better in seeds than in sheaths and the optimum temperature for the survival of the pathogen was observed to be $25 \pm 1^{\circ} \mathrm{C}$.

Maiti et al. (1991) reported that S. oryzae survived in rice seed for ten months at laboratory conditions. The variation in the survival periods of the fungus may be due to the moisture levels in seeds. The amount of fungal colonization of seed at the time of collection of seed may influence the period of survival of the fungus in seed. Gopalkrishnan and Valluvaparidasan (2006) found that $S$. oryzae survived for longer period in seed samples with initial 30 to 40 per cent seed infection by $S$. oryzae.

Similar results were also observed by Varati (2012) who reported that S. oryzae could survive in seed as long as 120 days, but its viability showed a decline with increase in the storage period. Decline of variability of the fungus in seed stored for longer period may be attributed to the depletion of moisture in seed.

\subsection{Survival and viability of $S$. oryzae in soil}

The results presented in Table 3.3, 3.4 and 3.5 revealed that $S$. oryzae survived upto 180 days in control plots where as it survived for 120 days in plot amended with dhaincha along with biofertilizer consortia and microbial antagonist at all the soil depth $(0 \mathrm{~cm}, 2 \mathrm{~cm}$ and $4 \mathrm{~cm}$ depth). The survival and viability of S.oryzae decreased with time at all the soil depths irrespective of amended or unamended soil. In the present investigation, it was found that S.oryzae survived for a shortest period (120 days) in plot amended with dhaincha compared to all other treatments, however, its population decreases with time at all the soil depth. On the other hand, $S$. oryzae survived for a longer period (180 days) in control plots, however, its population also decreases with time at all the soil depths. The possible reason for reduced survivability of $S$. oryzae in amended soil may be due to increased soil microbial growth, activity and diversity leading to enhanced suppressive capacity of the soil attributed to release of high amount of labile carbon by the organic amendments particularly dhaincha which serves as immediate source of food for the soil microorganisms which was in conformity with the findings of earlier workers (Stone et al. ,2004; Elliott and Lunch,1994).

Similar results were also observed by earlier researchers (Mazzola, 2004; Ali and Gogoi, 2004) who reported that green manures and organic amendments can reduce soil-borne pathogens through enhanced suppressive activity in soil. Baby and Manibhushanrao (1993) also reported that when fungal antagonists (Gliocladium virens and $T$. longibrachiatum) were supplemented with organic substrates through organic soil amendments (gliricidia leaf and neem cake), an increase in the c.f.u. of the antagonists and marked reduction in survival of rice sheath blight pathogen (Rhizoctonia solani) were noticed. Reduced survival of soil borne plant pathogens due to application of microbial antagonist was also reported by Sakthivel and Gnanamanickam (1986). The present findings are in conformity with the findings of Kanagasabai (1980), who reported that organic amendment in the form of sawdust and mahua cake reduced the survival of $S$. oryzae to a considerable extent. The antagonists applied to the soil survived well in the amended soil and reduced the pathogen population. The increased population of soil microbes in the amended soil as reported by several researchers (Baby and Manibhushanrao, 1993; Nakhro and Dkhar, 2010; Das and Dkhar,2012) has contributed towards reduction in survivability of S.oryzae and its population. Deka and Phookan (1998) also reported that the $S$. oryzae survived in soil sample stored for 210 days at $30 \pm$ $1^{\circ} \mathrm{C}$ and180 days in naturally infected field soil. Maiti et al. (1991) confirmed that the S. oryzae could be isolated from the soil samples collected from the rhizosphere of the rice crop. They also observed that $S$. oryzae survived in rhizosphere soil for more than six months. 
Table 3.3 Effect of organic amendments, biofertilizer consortia and $P f$ formulation on survival of $S$. oryzae at $0 \mathrm{~cm}$ soil depth

\begin{tabular}{|l|c|c|c|c|c|c|}
\hline \multirow{2}{*}{ Treatments } & \multicolumn{5}{|c|}{ Population of S.oryzae $\mathbf{x ~ 1 0}$ cfu/gm soil) } \\
\cline { 2 - 7 } & $1 \mathrm{MAH}$ & $2 \mathrm{MAH}$ & $3 \mathrm{MAH}$ & $4 \mathrm{MAH}$ & $5 \mathrm{MAH}$ & $6 \mathrm{MAH}$ \\
\hline $\mathrm{T}_{1=}$ Dhaincha $+\mathrm{BCEF}+P f$ & $6.36^{\mathrm{f}}$ & $4.34^{\mathrm{e}}$ & $3.65^{\mathrm{f}}$ & $1.68^{\mathrm{f}}$ & 0 & 0 \\
\hline $\mathrm{T}_{2}=$ Vermicompost $+\mathrm{BCEF}+P f$ & $10.34^{\mathrm{d}}$ & $8.36^{\mathrm{d}}$ & $6.31^{\mathrm{e}}$ & $3.65^{\mathrm{de}}$ & $2.32^{\mathrm{de}}$ & 0 \\
\hline $\mathrm{T}_{3}=\mathrm{Azolla}+\mathrm{BCEF}+P f$ & $8.68^{\mathrm{e}}$ & $7.31^{\mathrm{d}}$ & $5.65^{\mathrm{e}}$ & $3.32^{\mathrm{e}}$ & $1.68^{\mathrm{e}}$ & 0 \\
\hline $\mathrm{T}_{4}=\mathrm{BCEF}+P f$ & $12.34^{\mathrm{c}}$ & $10.32^{\mathrm{c}}$ & $7.36^{\mathrm{d}}$ & $4.64^{\mathrm{cd}}$ & $2.65^{\mathrm{cd}}$ & 0 \\
\hline $\mathrm{T}_{5}=\mathrm{BCEF}$ & $13.36^{\mathrm{c}}$ & $11.31^{\mathrm{c}}$ & $8.34^{\mathrm{c}}$ & $5.32^{\mathrm{cc}}$ & $3.34^{\mathrm{cc}}$ & 0 \\
\hline $\mathrm{T}_{6}=\mathrm{RDF}$ & $16.32^{\mathrm{b}}$ & $13.33^{\mathrm{b}}$ & $9.36^{\mathrm{b}}$ & $6.34^{\mathrm{b}}$ & $3.65^{\mathrm{ab}}$ & $1.65^{\mathrm{b}}$ \\
\hline $\mathrm{T}_{7}=\mathrm{Absolute}$ control & $18.34^{\mathrm{a}}$ & $15.32^{\mathrm{a}}$ & $10.35^{\mathrm{a}}$ & $7.65^{\mathrm{a}}$ & $4.32^{\mathrm{a}}$ & $2.32^{\mathrm{a}}$ \\
\hline $\mathrm{SEd} \pm$ & 0.67 & 0.57 & 0.44 & 0.55 & 0.45 & 0.27 \\
\hline $\mathrm{CD}(\mathrm{P}=0.05)$ & 1.47 & 1.25 & 0.96 & 1.19 & 0.98 & 0.59 \\
\hline
\end{tabular}

Table 3.4 Effect of organic amendments, biofertilizer consortia and $P f$ formulation on survival of $S$. oryzae at $2 \mathrm{~cm}$ soil depth.

\begin{tabular}{|c|c|c|c|c|c|c|}
\hline \multirow{2}{*}{ Treatments } & \multicolumn{6}{|c|}{ Population of S.oryzae $\left(\times 10^{4} \mathrm{cfu} / \mathrm{gm}\right.$ soil) } \\
\hline & $1 \mathrm{MAH}$ & $2 \mathrm{MAH}$ & $3 \mathrm{MAH}$ & $4 \mathrm{MAH}$ & $5 \mathrm{MAH}$ & $6 \mathrm{MAH}$ \\
\hline $\mathrm{T}_{1=}$ Dhaincha $+\mathrm{BCEF}+P f$ & $8.36^{\mathrm{e}}$ & $6.32^{\mathrm{e}}$ & $4.34^{\mathrm{f}}$ & $2.31^{\mathrm{d}}$ & 0 & 0 \\
\hline $\mathrm{T}_{2}=$ Vermicompost $+\mathrm{BCEF}+P f$ & $12.34^{\text {cd }}$ & $10.32^{\text {cd }}$ & $8.34^{\mathrm{d}}$ & $5.31^{\mathrm{c}}$ & $2.64^{\mathrm{cd}}$ & $\overline{0}$ \\
\hline $\mathrm{T}_{3}=$ Azolla $+\mathrm{BCEF}+P f$ & $10.68^{\mathrm{de}}$ & $8.36^{\mathrm{de}}$ & $6.35^{\mathrm{e}}$ & $4.64^{\mathrm{c}}$ & $2.32^{\mathrm{d}}$ & $\overline{0}$ \\
\hline $\mathrm{T}_{4}=\mathrm{BCEF}+P f$ & $14.34^{\mathrm{c}}$ & $12.32^{\mathrm{bc}}$ & $9.32^{\mathrm{cd}}$ & $6.34^{\mathrm{bc}}$ & $3.32^{\text {cd }}$ & $\overline{0}$ \\
\hline $\mathrm{T}_{5}=\mathrm{BCEF}$ & $15.32^{\mathrm{bc}}$ & $13.64^{b}$ & $10.36^{\mathrm{c}}$ & $7.31^{\mathrm{b}}$ & $3.65^{\mathrm{bc}}$ & $\overline{0}$ \\
\hline $\mathrm{T}_{6}=\mathrm{RDF}$ & $18.35^{\mathrm{ab}}$ & $16.32^{\mathrm{a}}$ & $12.34^{\mathrm{b}}$ & $9.32^{\mathrm{a}}$ & $4.68^{\mathrm{b}}$ & $2.32^{\mathrm{a}}$ \\
\hline $\mathrm{T}_{7}=$ Absolute control & $20.64^{\mathrm{a}}$ & $17.36^{\mathrm{a}}$ & $14.36^{\mathrm{a}}$ & $10.64^{\mathrm{a}}$ & $7.31^{\mathrm{a}}$ & $2.68^{\mathrm{a}}$ \\
\hline $\mathrm{SEd} \pm$ & 1.4 & 1.02 & 0.5 & 0.81 & 0.47 & 0.24 \\
\hline $\mathrm{CD}(\mathrm{P}=0.05)$ & 3.04 & 2.23 & 1.09 & 1.76 & 1.02 & 0.53 \\
\hline
\end{tabular}

Table 3.5 Effect of organic amendments, biofertilizer consortia and $P f$ formulation on survival of $S$. oryzae at $4 \mathrm{~cm}$ soil depth.

\begin{tabular}{|l|c|c|c|c|c|c|}
\hline \multirow{2}{*}{ Treatments } & \multicolumn{5}{|c|}{ Population of S.oryzae $(\mathbf{x ~ 1 0}$ cfu/gm soil) } \\
\cline { 2 - 7 } & $1 \mathrm{MAH}$ & $2 \mathrm{MAH}$ & $3 \mathrm{MAH}$ & $4 \mathrm{MAH}$ & $5 \mathrm{MAH}$ & $6 \mathrm{MAH}$ \\
\hline $\mathrm{T}_{1=}$ Dhaincha $+\mathrm{BCEF}+P f$ & $5.34^{\mathrm{f}}$ & $3.65^{\mathrm{e}}$ & $3.32^{\mathrm{f}}$ & $1.31^{\mathrm{d}}$ & 0 & 0 \\
\hline $\mathrm{T}_{2}=$ Vermicompost $+\mathrm{BCEF}+P f$ & $9.36^{\mathrm{d}}$ & $7.32^{\mathrm{d}}$ & $5.33^{\mathrm{de}}$ & $2.32^{\mathrm{cd}}$ & $1.68^{\mathrm{de}}$ & 0 \\
\hline $\mathrm{T}_{3}=$ Azolla+BCEF$+P f$ & $8.34^{\mathrm{e}}$ & $6.34^{\mathrm{d}}$ & $4.68^{\mathrm{e}}$ & $1.65^{\mathrm{d}}$ & $1.32^{\mathrm{e}}$ & 0 \\
\hline $\mathrm{T}_{4}=\mathrm{BCEF}+P f$ & $11.68^{\mathrm{c}}$ & $8.64^{\mathrm{c}}$ & $5.63^{\mathrm{cd}}$ & $3.32^{\mathrm{bc}}$ & $2.31^{\mathrm{cd}}$ & 0 \\
\hline $\mathrm{T}_{5}=\mathrm{BCEF}$ & $12.34^{\mathrm{c}}$ & $9.65^{\mathrm{c}}$ & $6.34^{\mathrm{c}}$ & $3.68^{\mathrm{b}}$ & $2.64^{\mathrm{bc}}$ & 0 \\
\hline $\mathrm{T}_{6}=\mathrm{RDF}$ & $15.35^{\mathrm{b}}$ & $11.34^{\mathrm{b}}$ & $8.34^{\mathrm{b}}$ & $4.36^{\mathrm{ab}}$ & $3.34^{\mathrm{ab}}$ & $1.32^{\mathrm{a}}$ \\
\hline $\mathrm{T}_{7}=\mathrm{Absolute}$ control & $17.34^{\mathrm{a}}$ & $13.36^{\mathrm{a}}$ & $9.36^{\mathrm{a}}$ & $5.32^{\mathrm{a}}$ & $3.64^{\mathrm{a}}$ & $1.64^{\mathrm{a}}$ \\
\hline $\mathrm{SEd} \pm$ & 0.44 & 0.49 & 0.39 & 0.47 & 0.45 & 0.24 \\
\hline $\mathrm{CD}(\mathrm{P}=0.05)$ & 0.96 & 1.06 & 0.84 & 1.02 & 0.98 & 0.52 \\
\hline
\end{tabular}

$\mathrm{BCEF}=$ Biofertilizer Consortia Enriched FYM, $P f=$ Pseudomonas fluorescens,

$\mathrm{RDF}=$ Recommended Dose of Fertilizer, $\mathrm{CFU}=$ Colony Forming Unit

$\mathrm{MAH}=$ Month After Harvest, Data are mean of four replications.

\section{Conclusion}

The survival and viability of the fungus significantly declined with increase in storage period both in infected stubbles and seeds.
However, the fungus could be isolated from infected stubbles and seeds upto150 and 210 days of storage, respectively irrespective of amended or unamended soil. The $S$. oryzae could survive only 
upto 120 days in dhaincha amended plot followed by 150 days in plots amended with azolla and vermicompost, respectively whereas, it could survive upto 180 days in the control plot at all the soil depths $(0 \mathrm{~cm}, 2 \mathrm{~cm}$ and $4 \mathrm{~cm})$ evaluated. However, in all the situations, the survival and viability of $S$. oryzae declined with increase in time.

\section{Acknowledgements}

The authors are thankful to Head, Department of Plant Pathology, Dean, College of Agriculture and Director of Post Graduate Studies, Assam Agricultural University, Jorhat for providing all the necessary facilities.

\section{References}

[1] Ali, M.S. and Gogoi, N.K. (2004).Integrated management of sheath blight of rice under rice-rice cropping system. J.Mycopath. Res.,42(2): 155-160.

[2] Baby, U.I. and Manibhushanrao, K.(1993). Control of rice sheath blight through the integration of fungal antagonists and organic amendments. Trop. Agriculture, 70(3):240-244.

[3] Christensen, C.M. and Kaufmann, M.M. (1965). Deterioration of stored grains by fungi. Annual review of Phytopathology, 3: 69-84.

[4] Das, B.B. and Dkhar, M.S.(2012). Organic amendment effects on microbial population and microbial biomass carbon in the rhizosphere soil of soybean. Commu. Soil Sci. Plant Analy., 43(14):1938-1948.

[5] Deka, A. K. and Phookam, A. K. (1998). Survival of Sarocladium oryzae causing sheath rot of rice in Acidic soils of Assam. J. Mycol. Pl. Pathol., 28(1): 55-56.

[6] Elliott, L. F. and Lunch, J. M. (1994). Biodiversity and soil resilience. In D. J. Greenland \& I. Szabolcs (Eds.), Soil resilience and sustainable land use. (pp. 353-364). CAB International., Wallingford, UK.

[7] Gamliel, A.; Austerweil, M. and Kritzman, G. (2000). Non-chemical approach to soilborne pest management - organic amendments. Crop Prot., 19: 847-853.

[8] Gomez, K. A. and Gomez, A. A.(1984). A Statistical Procedure for Agricultural Research. John Wiley and Sons, New york

[9] Gopalakrishnan, C. and Valluvaparidasan, V. (2006). Seed-borne biocontrol agents for the management of rice sheath rot caused by Sarocladium oryzae (Sawada) W. Gams \& D. Hawksw. J. Biol. Contr., 20(2):197-204.

[10] Kanagasbai, R.(1980).Studies on an integrated approach for the control of sheath rot disease of rice caused by Acrocylindrium oryzae Sawada. M.Sc. Thesis Annamalai Univ., India.

[11] Kawamura, E. (1940). Notes on the sheath rot of rice plant with special reference to its causal organism, Acrocylindrium oryzae Saw. Ann. Phytopath. Soc., Japan. 10:55-59.

[12]Kulkarni, M.; Chaudhari, R. and Chaudhari, A. (2007). Novel tensio-active microbial compounds for biocontrol applications. In: General Concepts in Integrated Pest and Disease Management (eds. A.Ciancio and K.G. Mukerji). Springer, 295-304.

[13] Kulwanth, S. and Mathur, S.B. (1992). Further evidence of transmission of Sarocladium oryzae through rice seeds and its quarantine significance. Indian Phytopath., 45(1):454 456.

[14]Maiti, D.; Variar, M. and Shukla, V. D.(1991). Off season perpetuation of Sarocladium oryzae under monocropped rainfed ecosystem. Indian Phytopath., 44(4): 454-457.

[15] Mazzola, M. (2004). Assessment and management of soil microbial community structure for disease suppression. Annu. Rev. Phytopath., 42: 35-39.

[16] Mohan, R. and Subramanium, C.L.(1981). Macco Agric. Digest., 5:3-4 (in sheath rot of rice by Alagarsamy, G. and Bhaskaran, R. In Advances in Rice Pathology. Kannaiyan, S. ed. 478 p.

[17] Nakhro, N. and Dkhar,M.S (2010). Impact of Organic and Inorganic Fertilizers on Microbial Populations and Biomass Carbon in Paddy Field Soil. J. Agron., 9(3):102-110.

[18] Prabhakaran, J.; Ragunathan, K. and Prasad, N.N. (1973). Occurrence of sheath rot disease of rice caused by Acrocylindrium oryzae Sawada. Annamalai Univ.Agric. Res. Ann., 5: 182183.

[19] Rajendran, N. (1979). Studies on the sheath rot disease of rice caused by Sarocladium attenuatum Gams and Hawksworth. M.Sc.(Ag) Thesis submitted to Tamil Nadu Agricultural University, Coimbatore, Tamil Nadu. 
[20]Reddy, M.M.; Reddy, C. S. and Gopal, S.B. (2000). Effect of sheath rot disease on quality characters of rice grain. J. Mycol. Pl. Pathol., 30(1):68-72.

[21]Reddy, M.M.; Reddy, C. S. and Reddy, A.G.R. (2001). Influence of weather parameters and insect populations on incidence and development of sheath rot of rice. Indian Phytopath., 54(2):179-184.

[22]Reddy, T.C.V.; Reddy, S. ; Rao, A.A. and Rao, D.K. (1974). A note on sheath rot of rice from India. J. Res. Andh.Prad. Agric. Univ., 2(3): 136-138.

[23] Sachan, I.P. and Agrawal, V.K. (1995). Seed discoloration of rice: location of inoculum and influence on nutritional value. Indian Phytopath., 48(1): 14-20.

[24] Sakthivel , N. and Gnanamanickm, S.S. (1987). Evaluation of P. fluorescens for suppression of sheath rot disease and for enhancement of grain yields in rice(Oryza sativa L.). Appl.Environ. Microbiol., 53(9):2056-2059.

[25] Shahjahan, A.K.M.; Harahap, Z. and Rush, M.C.(1977). Sheath rot of rice caused by Acrocylindrium oryzae in Louisiana. Plant Dis. Reptr.,61:307-310.
[26] Singh, R.A. and Raju, C.A.(1980). Survival studies on the Sarocladium oryzae the causal agent of sheath rot of rice. Indian Phytopath., 33:148.

[27] Stone, A. G.; Scheuerell, S. J.and Darby, H. M. (2004). Suppression of soilborne diseases in field agricultural systems: organic matter management, cover cropping, and other cultural practices. In F. Magdoff \& R. R. Weil (Eds.), Soil Organic Matter in Sustainable Agriculture. (pp. 131-178). CRC Press LLC.

[28] Tenuta, M. and Lazarovits, G. (2002a). Identification of specific soil properties that affect the accumulation and toxicity of ammonia to Verticillium dahliae. Can. J. Pl. Pathol., 24: 219-229

[29] Varati, U. (2012). Studies on sheath rot disease of rice caused by Sarocladium oryzae (sawada) Gams and Hawksworth. M.Sc.(Agri.) thesis, Acharya N.G. Ranga Agricultural University Rajendranagar, Hyderabad.

[30] Waksman, S.A. (1922). A method for counting the number of fungi in the soil. J. Bact.,7

(3):

339-341. 